\title{
Anti-proliferative and apoptotic efficacy of diallyl disulfide on Ehrlich ascites carcinoma
}

\author{
Osama M. Ahmed ${ }^{1,2}$, Rasha R. Ahmed ${ }^{3}$ \\ ${ }^{1}$ Physiology Division, Zoology Department, Faculty of Science, Beni-Suef University, Beni-Suef 62514, Egypt \\ ${ }^{2}$ Faculty of Oral and Dental Medicine, Nahda University, Beni-Suef 11787, Egypt \\ ${ }^{3}$ Cell Biology, Histology and Genetics Division, Zoology Department, Faculty of Science, Beni-Suef University, Beni-Suef 62514, Egypt
}

\begin{abstract}
Aim: This study was conducted to assess the in vivo and in vitro anti-tumor effects of diallyl disulfide (DADS) against Ehrlich ascites carcinoma (EAC) and to suggest its probable mechanism of action. Methods: EAC was induced in female mice by intraperitoneal injection of EAC-cells from stock mice. EAC-bearing mice were orally treated with $100 \mathrm{mg} / \mathrm{kg}$ body weight for 2 weeks beginning from the 1st day of EAC intraperitoneal transplantation. Cytotoxicity effects of DADS against EAC-cells in vitro were investigated at different concentrations $(0,6.25,12.5,25,50$, and $100 \mu \mathrm{g} / \mathrm{mL})$ of DADS using trypan blue exclusion assay. Results: Data from this study exhibited a significant decrease in EAC-aliquot volume as well as total and alive EAC-cell number and a marked increase in dead EAC-cell number and percent in EAC-bearing mice treated with DADS as compared with EAC-bearing control. These changes were consistent with increased number of cells which exhibited phenotypic apoptotic signs marked by a decrease in the expression of anti-apoptotic protein Bcl-2, an increase of pro-apoptotic and cell cycle arrest mediator p53 and an elevation of DNA fragmenting indicator terminal deoxynucleotidyl transferase in EAC-bearing mice treated with DADS. In addition, the tumor marker sialic acid level was markedly decreased in plasma and Ehrlich ascites in EAC-bearing mice treated with DADS. In vitro, DADS also produced anti-proliferative and anti-tumor cytotoxic potentials against EAC. Conclusion: DADS may have anti-cancer effects which may be mediated via modulation of apoptosis and cell cycle arrest.
\end{abstract}

Key words: Anti-proliferative effects; apoptosis; diallyl disulfide; Ehrlich ascites carcinoma; imaging; semi-quantitative analysis

Address for correspondence:

Prof. Osama M. Ahmed, Physiology Division, Zoology Department, Faculty of Science, Beni-Suef University, Beni-Suef 62514, Egypt. E-mail: osama.ahmed@science.bsu.edu.eg

Received: 29-01-2015, Accepted: 27-04-2015

\section{INTRODUCTION}

Cancer still has a high mortality rate. Recently, considerable attention has been focused on identifying naturally occurring chemopreventive and chemotherapeutic substances capable of inhibiting, retarding or reversing the multistage carcinogenesis. ${ }^{[1]}$ Thus, a preventive and/or therapeutic use

\begin{tabular}{|l|c|}
\hline \multicolumn{2}{|c|}{ Access this article online } \\
\hline \multirow{2}{*}{ Website: } & Quick Response Code \\
\hline http://www.hrjournal.net/ & \\
DOI: & \\
10.4103/2394-5079.157602 & \\
&
\end{tabular}

of phytochemicals could open new avenues in the search for strategies against proliferation of tumor cells. It was found by many authors that numerous biologically active phytochemicals kill cancer cells by targeting epigenetic alterations that occur during carcinogenesis and by affecting the cell cycle which is tightly regulated by a series of cell cycle regulators. ${ }^{[2,3]}$

Organosulfur compounds of garlic including diallyl disulfide (DADS) exhibit a wide range of biological activities, including anti-mutagenic, anti-oxidant, anti-proliferative effects which could protect against critical events that are involved in the cancer process. ${ }^{\mid 4-8]}$ In addition, available epidemiologic evidence is consistent in showing a correlation between consumption of the high amount of garlic and a reduced risk of cancer, particularly colon cancer, at 
most sites. ${ }^{[9]}$ Moreover, many publications attributed the anti-carcinogenic properties of garlic principally to allyl sulfides, among them DADS, which was shown to suppress growth and facilitate the death of different tumor cells. ${ }^{[2,6-10]}$

This study was designed to assess the anti-proliferative and anti-tumor cytotoxic efficacies against Ehrlich ascites carcinoma (EAC) (which corresponds to mammary adenocarcinoma in female mice) in vivo and in vitro. In addition, the apoptogenic effect of DADS was assessed via following the changes in the anti-apoptotic protein, $\mathrm{Bcl}-2$ and apoptotic markers, p53 and terminal deoxynucleotidyl transferase (TdT) by immunohistochemical methods, imaging and semi-quantitative analysis. The experimental study was approved by review board of Beni-Suef University.

\section{METHODS}

\section{Tested agent (DADS)}

DADS $\left(\mathrm{C}_{6} \mathrm{H}_{10} \mathrm{~S}_{2}\right)$ was obtained from Fluka Chemie GmbH, Buchs, Switzerland (lot and filling code 427432/1 55004115). DADS was dissolved in dimethyl sulfoxide (DMSO) for in vivo and in vitro studies and was administered orally by gastric gavage at dose level of $100 \mathrm{mg} / \mathrm{kg}$ body weight (b.w.)/day ${ }^{[11]}$ for 2 weeks. Its structure is $\mathrm{CH}_{2}=\mathrm{CH}-\mathrm{CH}_{2}-\mathrm{S}-\mathrm{S}-\mathrm{CH}_{2}-\mathrm{CH}=\mathrm{CH}_{2}$ as indicated in the previous publication. ${ }^{[12]}$

\section{Animals and EAC-bearing model}

Normal albino mice were obtained from Animal House, Institute of Ophthalmology, Giza, Egypt. EAC-bearing stock mice were obtained from Cancer Biology Department, National Cancer Institute, Cairo University, Egypt. To induce EAC in mice for the experimental study, $0.2 \mathrm{~mL}$ EAC aliquot aspirated from stock mice was added to $9.8 \mathrm{~mL}$ saline (dilution is 1:50) and $0.2 \mathrm{~mL}$ of this diluted EAC was intraperitoneally administered by syringe into each mice.

\section{Animal grouping}

The EAC-injected mice were divided into two groups each containing 12 animals. Mice in group 1 (control group) were administered $10 \%$ DMSO as a vehicle in a volume equivalent to that given to treated animals. Group 2 was treated with DADS, dissolved in $10 \%$ DMSO, at a dose of $100 \mathrm{mg} / \mathrm{kg}$ b.w. The treatments were orally applied by gastric intubation between 10 and $12 \mathrm{AM}$ daily for 2 weeks beginning from the 1 st day of EAC-intraperitoneal inoculation.

\section{Animal survival}

The number of animals survived in each group was determined at the end of the experiment and the survival percent in each group was calculated as follows: survival percent $=$ (number of survived animals/total number of animals) $\times 100$.

\section{Sampling and detection of EAC-volume and cell number} At the end of the experimental period, animals were sacrificed under diethyl ether anesthesia and $0.2 \mathrm{~mL}$ saline was intraperitoneally injected. One minute later, EAC-aliquot was aspirated by a sterile syringe into a test tube. The volume of EAC-fluid for each mouse was measured. The number of alive and dead EAC-cells were determined using trypan blue exclusion assay. ${ }^{[13]}$ Alive and dead EAC-cells were counted by Neubauer hemocytometer. Briefly, $40 \mu \mathrm{L}$ of EAC-aliquot was added to $4 \mathrm{~mL} 2 \%$ trypan blue (dissolved in $0.9 \%$ saline) and the mixture was left for $5 \mathrm{~min}$. One drop from the mixture was taken on Neubauer hemocytometer and the number of stained cells (dead cells) and nonstained cells (viable or alive cells) were counted. Total number of EAC-cells and percent of dead EAC-cells were calculated for each EAC-bearing mouse. This procedure was adopted from the methods of Freitas et al..$^{[14]}$ and Chandru et al..$^{[15]}$

Blood samples were obtained from carotid artery of each mouse into ethylenediaminetetraacetic acid (15\%)-containing tubes under mild diethyl ether anesthesia and were centrifuged at 3,000 $\mathrm{g}$ for $15 \mathrm{~min}$. The plasma was aspirated into Eppendorf tubes and kept in deep freezer at $-30{ }^{\circ} \mathrm{C}$ until used for plasma sialic acid determination. One milliliter of EAC fluid from each mouse was homogenized in $2 \mathrm{~mL}$ saline $(0.9 \% \mathrm{NaCl})$ and centrifuged at 3,000 $\mathrm{g}$ for $15 \mathrm{~min}$. The supernatant was aspirated into Eppendorf tubes and kept in deep freezer at $-30{ }^{\circ} \mathrm{C}$ until used for ascites sialic acid determination.

Part of EAC-aliquot from each tumor-bearing mouse was centrifuged at $3,000 \mathrm{~g}$ for $15 \mathrm{~min}$ and the precipitated EAC-cells were fixed in neutral buffered formalin for histological and immunohistochemical studies.

\section{Determination of plasma and ascites sialic acid concentration}

Plasma and ascites sialic acid level was determined according to the method of Warren. ${ }^{[16]}$ In this method, sialic acid is oxidized into formylpyruvic acid which reacts with thiobarbituric acid to form a pink color product. The color intensity measured at $549 \mathrm{~nm}$ is proportional to the concentration of sialic acid in the sample.

\section{Histological and immunohistochemical investigations}

The fixed samples were transferred to the Department of Pathology, National Cancer Institute for processing, blocking, sectioning and staining with hematoxylin and eosin or mounting on positive slides for immunhistochemical investigations. Sections mounted onto positive-charged slides (Fisher Scientific, Pittsburgh, PA, USA) were used to detect the $\mathrm{Bcl}-2$ and p53 reactivity or apoptotic cells using 
the TdT-mediated dUTP nick end labeling (TUNEL) assay. ${ }^{[17]}$ The TUNEL assay was performed using a kit (in situ cell death detection kit, Roche Molecular Biochemicals, Manheim, Germany) according to the protocol provided by the manufacturer, while $\mathrm{Bcl}-2$ and $\mathrm{p} 53$ reactivity were determined following method of Gao and Zhou. ${ }^{[18]}$ Briefly, before the incubation with antibodies, endogenous peroxidase activity was quenched, slides washed and then incubated in a blocking solution of hydrogen peroxide $1 \%$ in methanol, in darkness for $15 \mathrm{~min}$. Antigen retrieval occurred in citrate buffer $10 \mathrm{mmol} / \mathrm{L}, \mathrm{pH}=6.0$. After cooling, sections were rinsed in tap water and then phosphate buffer saline (PBS). Primary antibodies for either Bcl-2 (DakoCytomation, USA) or p53 (Lab Vision Corporation, 47777 Warm Springs Blvd, Fremont, CA, USA), diluted $1: 150$ and 1:100, respectively in PBS, were applied for $1 \mathrm{~h}$ at $37^{\circ} \mathrm{C}$. Secondary biotinylated antibody diluted $1: 100$ and $1: 200$ in PBS was applied for a period of $30 \mathrm{~min}$ at $37^{\circ} \mathrm{C}$. Streptavidin-biotin or avidin-biotin complex with horseradish peroxidase (ABC/HRP) was applied for $10 \mathrm{~min}$ at room temperature. Bound antibody complex was visualized by the reaction of 3, 3'-diaminobenzidine (DAB) substrate and counterstained with hematoxylin. Secondary biotinylated antibody, ABC/HRP and DAB were obtained from Zymed Laboratories (Invitrogen Immunoprotection, 561 Eccles Avenue, South San Francisco, CA, USA). Hematoxylin was obtained from Sigma Chemical Company, USA.

Imaging and semi-quantitative analysis of Bcl-2, p53 and terminal deoxynucleotidyl transferase

The yellowish brown colored stained area were analyzed in pixels; percent area and intensity were detected by ImageJ software, US National Institutes of Health, Bethesda, Maryland, USA (http://imagej.nih.gov/ij/).

\section{Anti-tumor cytotoxicity against EAC-cells in vitro}

The viability of cells as a result of 6 different concentrations $(0,6.25,12.5,25,50$, and $100 \mu \mathrm{g} / \mathrm{mL})$ of DADS was tested by trypan blue exclusion assay according to the method of Ahmed and Ahmed. ${ }^{[19]}$ Briefly, EAC-cells at concentration $2.5 \times 10^{5}$ cells/mL suspended in PBS were incubated at $37^{\circ} \mathrm{C}$ for $2 \mathrm{~h}$ in the presence of different concentrations of DADS dissolved in dimethyl sulfoxide. At the end of incubation period, equal volume of trypan blue solution was added to sample cells, then the stained cells (dead cells) and unstained cells (alive cells) were counted using Neubauer hemocytometer. The percent of dead cells for each test was calculated.

\section{Statistical analysis}

Data were analyzed by one-way analysis of variance (ANOVA) followed by a least significance difference (LSD) test to compare the groups with each other. ${ }^{[20]}$ Data were expressed as mean \pm standard error. Values with $P>0.05$ are not significantly different while values with $P<0.05$ and $P<0.01$ are significantly and highly significantly different respectively. F-probability expresses the general effect between groups.

\section{RESULTS}

\section{Effects on animal survival and mortality}

After 2 weeks of EAC-intraperitoneal transplantation, 8 of 12 mice administered $10 \%$ DMSO as a vehicle survived; the survival percentage was $66.66 \%$. The treatment of EAC-bearing mice with DADS markedly increased the survival percentage to reach $83.33 \%$ at the end of the experiment [Table 1].

\section{Effects on EAC-fluid volume and cell number in vivo}

The inhibitory effect of DADS on EAC-cells in vivo was tested in terms of EAC-fluid volume, number of total and alive EAC-cells, and number and percent of EAC-dead cells. The daily treatment of EAC-bearing mice with DADS for 2 weeks after EAC-cells intraperitoneal transplantation induced a significant decrease (LSD; $P<0.05$ ) of EAC-fluid volume, number of total and alive EAC-cells. On the other hand, the number and percent of dead EAC-cells exhibited a potential increase (LSD; $P<0.01$ ) as compared to EAC-bearing control counterparts. The ratio of EAC-fluid volume to total EAC-number was also highly significantly (LSD; $P<0.01$ ) increased in EAC-bearing mice treated with DADS as compared with control mice [Table 1].

With regards to one-way ANOVA, it was found that the effect between groups on number of total and alive EAC-cells and percent of dead cells was very highly significant (F-probability; $P<0.001$ ), while the effect on EAC-volume and number of dead cells was only highly significant $(P<0.01)$ [Table 1].

\section{Effect on plasma and ascites sialic acid level in vivo}

Plasma sialic acid level in EAC-bearing mice was highly significantly $(P<0.01 ;-35.05 \%)$ decreased as a result of treatment with DADS. The ascites sialic acid concentration was also highly significantly $(P<0.01 ;-28.49 \%)$ decreased in EAC-bearing mice treated with DADS as compared with EAC-bearing control [Table 2].

Histological and immunohistochemical effects on EAC-cells As indicated by low and high magnification, EAC cells of EAC-bearing control female mice [Figure 1a and c] were characterized with abundant basophilic and dark stained cytoplasm as well as moderate sized nuclei. As a result of treatment with DADS [Figure 1b and d], EAC-cells decreased in number and size and appeared with a narrow rim of 
Table 1: Effect of DADS administration on animal survival percent EAC-aliquot volume, EAC-cells number and percent of dead cells in EAC-bearing mice

\begin{tabular}{lccccccc}
\hline Groups & $\begin{array}{c}\text { Animal survival } \\
\text { percent }(\%)\end{array}$ & $\begin{array}{c}\text { EAC-aliquot } \\
\text { volume }(\mathrm{mL})\end{array}$ & $\begin{array}{c}\text { Total EAC-cell } \\
\text { number }\left(\times 10^{7}\right)\end{array}$ & $\begin{array}{c}\text { EAC-aliquot volume/ } \\
\text { total EAC-number }(\%)\end{array}$ & $\begin{array}{c}\text { Alive EAC-cell } \\
\text { number }\left(\times 10^{7}\right)\end{array}$ & $\begin{array}{c}\text { Dead EAC-cell } \\
\text { number }\left(\times 10^{7}\right)\end{array}$ & $\begin{array}{c}\text { Percent of } \\
\text { dead EAC-cells }\end{array}$ \\
\hline $\begin{array}{l}\text { EAC-bearing mice } \\
\text { control }(n=8)\end{array}$ & 66.66 & $6.56 \pm 0.49$ & $121.31 \pm 14.13$ & $5.41 \pm 0.63$ & $118.33 \pm 13.64$ & $2.71 \pm 0.23$ & $2.38 \pm 0.19$ \\
EAC-bearing & & & & & & & \\
mice treated with & 83.33 & $4.90 \pm 0.19^{* *}$ & $51.81 \pm 4.24^{* *}$ & $9.46 \pm 0.61^{* *}$ & $48.09 \pm 4.27^{* *}$ & $3.72 \pm 0.19^{* *}$ & $7.61 \pm 0.98^{* *}$ \\
DADS $(n=10)$ & & & & & & & \\
F-probability & - & $P<0.01$ & $P<0.001$ & $P<0.001$ & $P<0.001$ & $P<0.01$ & $P<0.001$ \\
LSD at the 5\% level & - & 1.027 & 28.45 & 2.51 & 27.62 & 0.63 & 2.38 \\
LSD at the 1\% level & - & 1.416 & 39.20 & 3.64 & 38.05 & 0.86 & 3.28 \\
\hline
\end{tabular}

Data are expressed as mean $\pm \mathrm{SE}$. ${ }^{*} P<0.01$ : effect is highly significant; difference between two means of the same parameter is higher than the value of LSD at the 1\% level. EAC: Ehrlich ascites carcinoma; DADS: diallyl disulfide; LSD: least significance difference; SE: standard error

Table 2: Effect of DADS administration on plasma and ascites sialic acid concentration in EAC-bearing mice

\begin{tabular}{lccc}
\hline Groups & $\begin{array}{c}\text { Plasma sialic acid } \\
\text { concentration }(\mathrm{mg} / 100 \mathrm{~mL})\end{array}$ & $\begin{array}{c}\text { Percent change } \\
\text { concentration }(\mathrm{mg} / \mathrm{g} \text { protein) }\end{array}$ & $\begin{array}{c}\text { Ascites sialic acid } \\
\text { Percent change }\end{array}$ \\
\hline EAC-bearing mice control $(n=8)$ & $91.72 \pm 1.26$ & -35.05 & $172.74 \pm 4.72^{* *}$ \\
EAC-bearing mice treated with DADS $(n=10)$ & $59.57 \pm 4.99^{* *}$ & $P<0.001$ & -28.49 \\
F-probability & $P<0.001$ & 24.84 \\
LSD at the 5\% level & 12.13 & 34.23 \\
LSD at the 1\% level & 16.71 & &
\end{tabular}

Data are expressed as mean \pm SE. ${ }^{* *} P<0.01$ : difference is highly significant; difference between two means is higher than value of LSD at the $5 \%$ level. EAC: Ehrlich ascites carcinoma; DADS: diallyl disulfide; LSD: least significance difference; SE: standard error

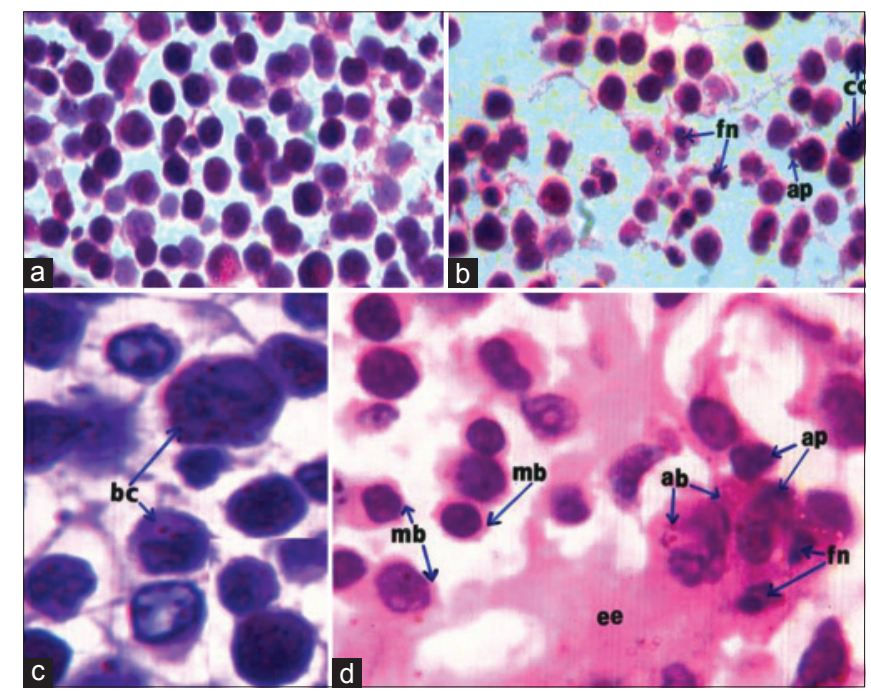

Figure 1: Photomicrographs of HE stained EAC-cells sections showing decreased number of cells, plasma membrane blebbing $(\mathrm{mb})$, fragmenting nuclei (fn), chromatin compaction or condensation (cc), apoptotic bodies (ap) and extracellular exudates $(e e)(b, \times 100 ; d, \times 1000)$, as a result of treatment of EAC-bearing mice with DADS as compared to EAC-bearing control mice (a, $\times 100 ; c, \times 1000)$ which have EAC-cells with bigger size, abundant basophilic cytoplasm (bc), and moderate sized-nuclei. EAC: Ehrlich ascites carcinoma; DADS: diallyl disulfide

light stained eosinophilic cytoplasm with azurophilic lytic bodies. Many EAC-cells, after treatment with DADS, exhibited apoptotic signs including shrinkage, blebbing plasma membrane, apoptotic bodies, nuclear chromatin compaction, and fragmenting nuclei. Between EAC-cells, there was a large amount of eosinophilic material or exudates.
After noticing that DADS induces EAC-apoptosis, the changes in anti-apoptotic protein $\mathrm{Bcl}-2$ and pro-apoptotic mediator p53 as well as DNA fragmenting marker TdT were followed to determine the mechanism of EAC killing.

As indicated in Figure 2, the treatment of EAC-bearing mice with DADS induced a potential decrease of $\mathrm{Bcl}-2$ expression (yellowish brown color) in the cytoplasm of EAC-cells [Figure 2b] as compared to the control [Figure 2a]. In contrast, p53 protein concentration was noticeably increased in the cytoplasm and nuclei of EAC-cells of DADS-treated mice [Figure 2d] as compared to the control [Figure 2c]. Similarly, TdT expression was remarkably increased in the nuclei of EAC-cells in DADS-treated mice [Figure 2f] as compared with the control counterpart [Figure 2e].

\section{Data of imaging and semi-quantitative analysis}

Imaging and semi-quantitative analysis results are represented in Figures 3 and 4.

Photomicrographs obtained from imaging analysis depicted that the amount of expressed $\mathrm{Bcl}-2$ has clearly decreased in EAC-bearing mice treated with DADS [Figure 3b] as compared to EAC-bearing control mice [Figure 3a]. On the other hand, the expressed p53 [Figure 3d] and TdT [Figure 3f] are much higher in EAC-bearing mice treated with DADS than in those of the corresponding EAC-bearing controls [Figure $3 \mathrm{c}$ and e]. 


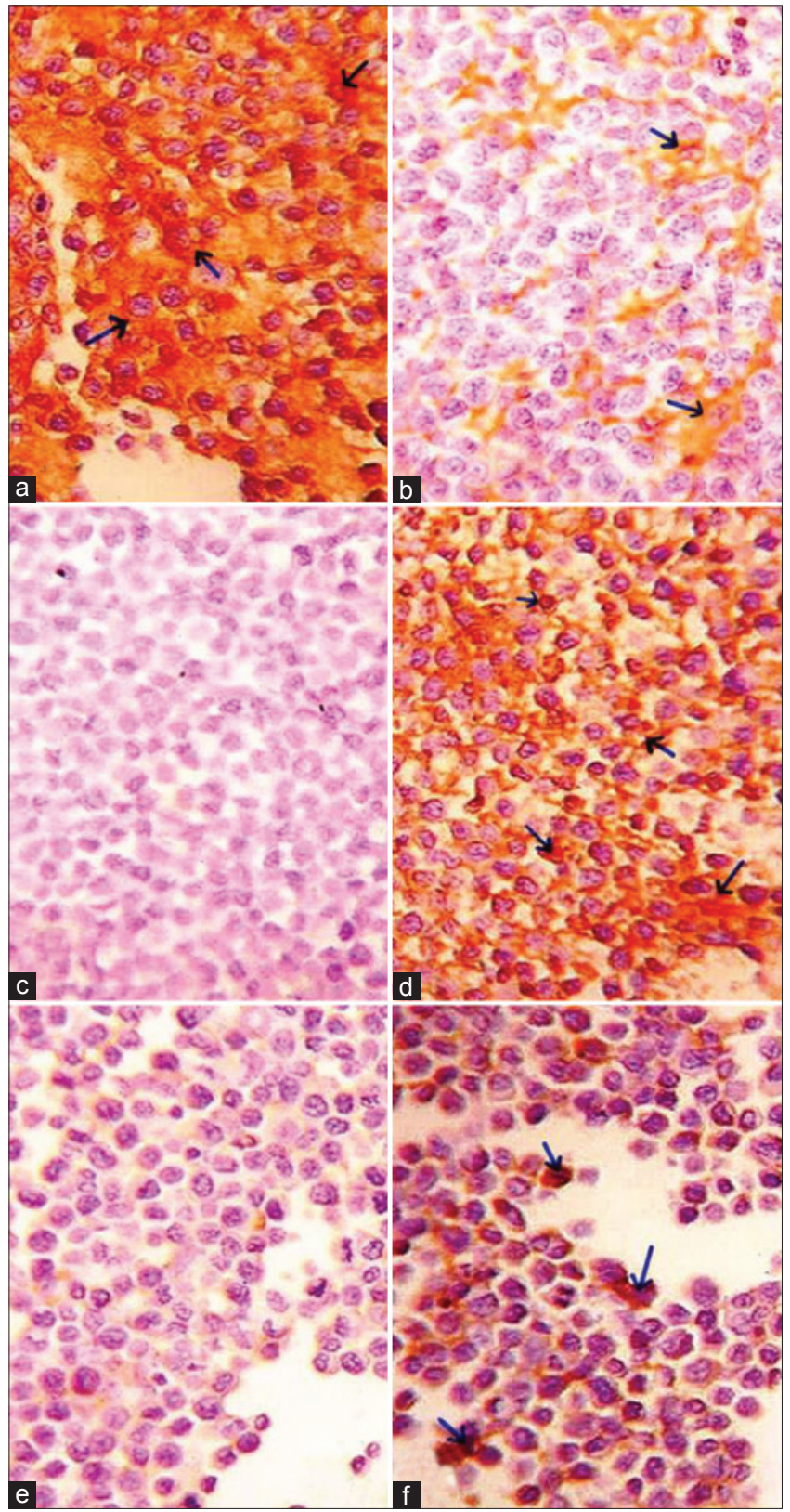

Figure 2: Photomicrographs of immunohistochemically stained EAC-sections. Images respectively show the greater amount of Bcl-2 (arrow; yellowish brown color) in the cytoplasm of EAC-cells in control mice $(a, \times 100)$ as compared with mice treated with DADS $(b, \times 100)$, the higher amount of p53 (arrow; yellowish brown color) in the cytoplasm and nuclei of EAC-cells in mice treated with DADS $(d, \times 100)$ than in EAC-bearing control mice $(c, \times 100)$, and the higher level of TdT (arrow; yellowish brown color) in the nuclei of EAC-cells in mice treated with DADS $(f, \times 100)$ than in EAC-bearing control mice $(e, \times 100)$. EAC: Ehrlich ascites carcinoma; DADS: diallyl disulfide; TdT: terminal deoxynucleotidyl transferase

As indicated in Figure 4, the area in pixels, percent area and intensity of yellowish brown color of immunoreactive anti-apoptotic marker, Bcl-2, were remarkably decreased in EAC-bearing mice treated with DADS as compared to those of EAC-bearing control mice. In contrast, the area in pixels, percent area and intensity of yellowish brown color of immunoreactive apoptotic markers, p53 and TdT were

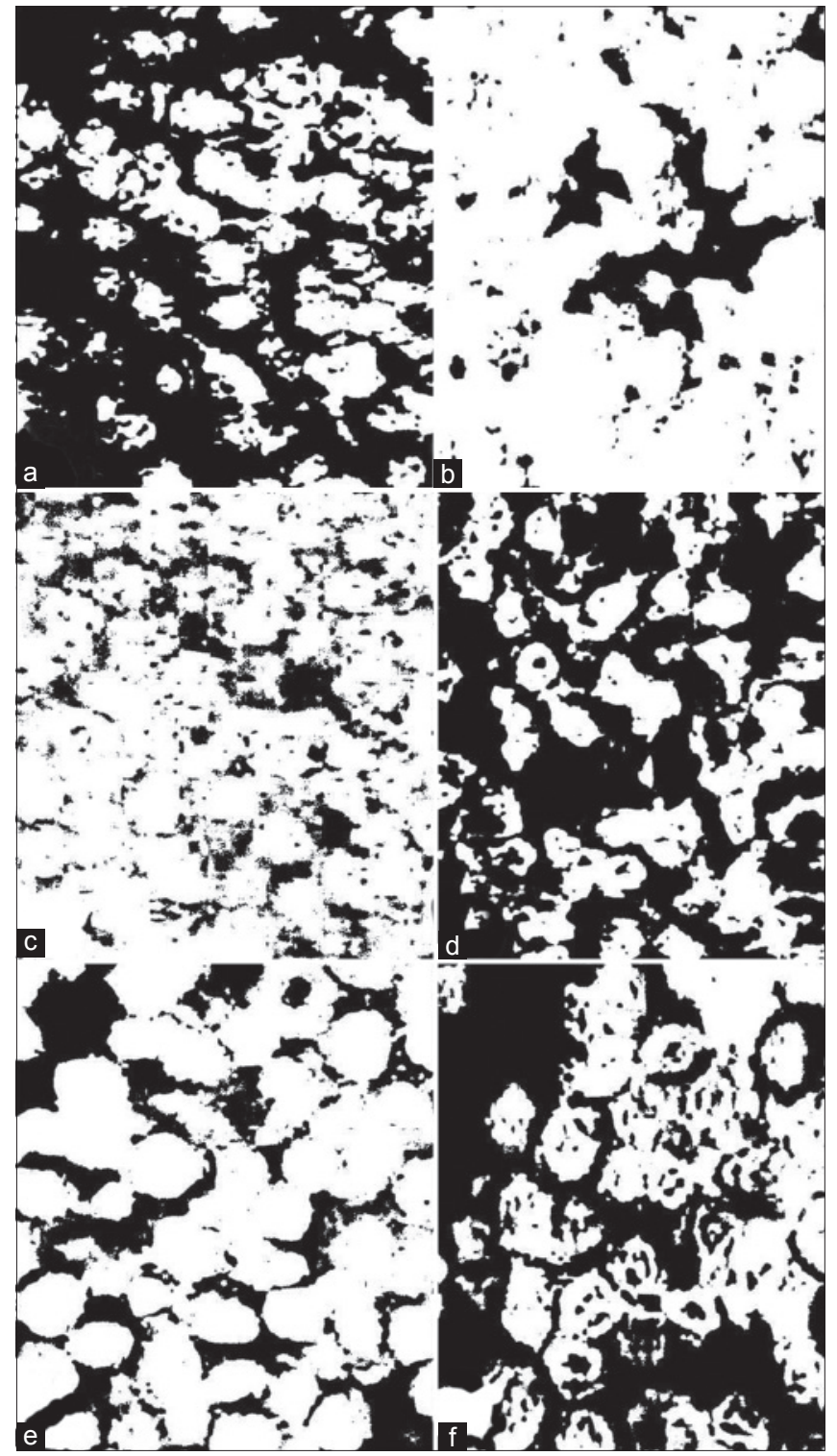

Figure 3: Photomicrographs of image analysis of immunohistochemically stained EAC-sections for Bcl-2 (b), p53 (d) and TdT ( $f$ ) of EAC-bearing mice treated with DADS as compared to their respective EAC-bearing mice controls ( $a, c$ and e). The black colored areas reflect the yellowish brown stained areas. The figures depict a decreased expression of $\mathrm{Bcl}-2$ and an increased expression of p53 and TdT as a result of treatment with DADS. EAC: Ehrlich ascites carcinoma; DADS: diallyl disulfide; TdT: terminal deoxynucleotidyl transferase

potentially elevated in EAC-bearing mice treated with DADS as compared with those of EAC-bearing control mice.

\section{Effects on EAC cells in vitro}

Incubation of EAC-cells $\left(2.5 \times 10^{5} / \mathrm{mL}\right.$ suspended in PBS $)$ with $0,6.25,12.5,25,50$, and $100 \mu \mathrm{g} / \mathrm{mL}$ of DADS (dissolved in DMSO) for $2 \mathrm{~h}$ produced 0, 16.5\%, 35\%, 70\%, 90\%, and $100 \%$ inhibition of cell viability, respectively. Thus, the effect seemed to be dose dependent and IC50 was $19.500 \mu \mathrm{g} / \mathrm{mL}$ [Table 3]. 


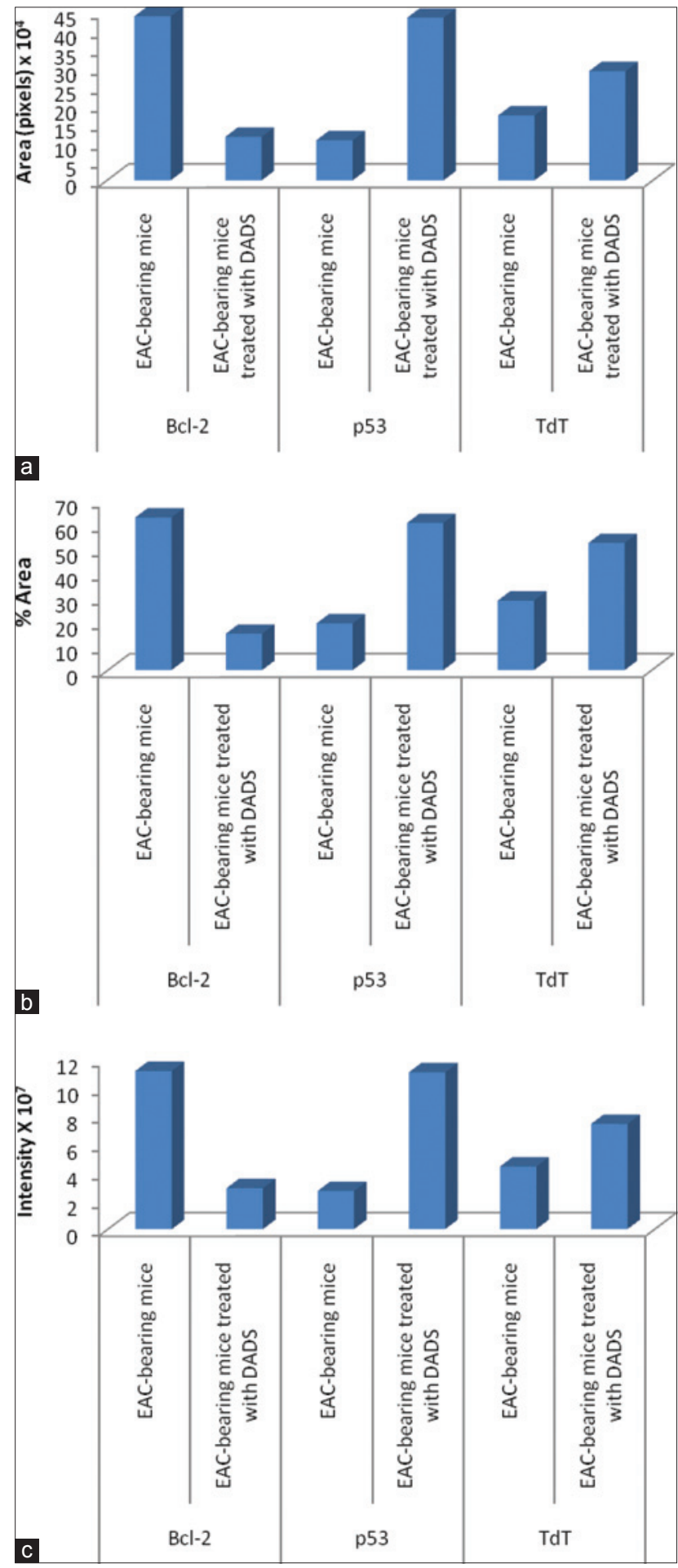

Figure 4: Data of image analysis of immunohistochemically stained EAC-sections showing (a) area in pixels, (b) percent area, and (c) the intensity of yellowish brown color of immunoreactive Bcl-2, p53 and TdT. EAC: Ehrlich ascites carcinoma; DADS: diallyl disulfide; TdT: terminal deoxynucleotidyl transferase

\section{DISCUSSION}

The goal of cancer chemoprevention is to slow, to block or to reverse the process of carcinogenesis. With regard to this principle, the study is a trial to evaluate the anti-tumor
Table 3: Effect of DADS, at various concentrations, on percent inhibition of EAC-cell viability in vitro

\begin{tabular}{lcccccr}
\hline Compound & \multicolumn{6}{c}{ Percentage of inhibition of cell viability $(\mu \mathrm{g} / \mathrm{mL})$} \\
\cline { 2 - 7 } & 0 & 6.25 & 12.5 & 25 & 50 & 100 \\
\hline DADS & 0 & 16.5 & 35 & 70 & 90 & 100 \\
\hline
\end{tabular}

IC50: $19.500 \mu \mathrm{g} / \mathrm{mL}$. EAC: Ehrlich ascites carcinoma; DADS: diallyl disulfide

cytotoxicity effects of DADS against EAC in vivo and in vitro. In addition, the apoptogenic effects of this agent were assessed by investigating the histological changes and measuring some apoptotic and anti-apoptotic mediators by imaging and semi-quantitative analysis of immunohistochemically stained sections of EAC-cells.

The current in vivo study revealed that DADS has a potential antiproliferative and cytotoxicity effect against EAC (a transplantable neoplasia from a malignant epithelium that corresponds to mammary adenocarcinoma) in EAC-bearing female mice. ${ }^{[14,21]}$ This activity was confirmed by a significant decrease in EAC-aliquot volume and total and alive EAC-cell number, and a tremendous increase in dead EAC-cell count and percent as a result of treatment with DADS in comparison to a vehicle. The anti-tumor cytotoxicity of DADS was associated with an improved survival and increased the life span of EAC-bearing mice. The plasma and Ehrlich ascites tumor marker, sialic acid, was significantly decreased in EAC-bearing mice treated with DADS as compared to EAC-bearing control mice. These in vivo results were supported by in vitro study which indicated that DADS induced unexpected anti-proliferative and anti-tumor cytotoxicity effects against EAC-cells.

In concurrence with the present results, the sialic acid, the component of glycoproteins and glycolipids that constitute the cell surface, was reported to be shed or secreted by tumor cells leading to its increased level in blood of humans with cancer and in animal cancer models. ${ }^{\mid 22]}$ The sialic acid level in serum and plasma was reportedly decreased in C57BL/6 mice lung metastasis of B16F-10 melanoma cells ${ }^{[23 \mid}$ and in alloxan diabetic rats, ${ }^{[24]}$ respectively. The anti-proliferative and apoptotic effects of DADS derived from Allium sativum in different carcinomas both in vivo and in vitro were also elucidated by various authors. ${ }^{\mid 25-27]}$

The histological findings of this study indicated that many cells seemed apoptotic, after treatment with DADS, as they were shrunk and had blebbing plasma membrane, apoptotic bodies and fragmenting nuclei which are considered as phenotypical or morphological signs of apoptosis. ${ }^{[28]}$ In addition to these histological results, immunohistochemical results depicted that the expression of $\mathrm{Bcl}-2$ working primarily by blocking apoptotic pathway, ${ }^{[29]}$ was noticeably 
reduced while the pro-apoptotic and anti-tumor suppressor protein p53 causing cell cycle arrest of EAC-cells, ${ }^{[30-32]}$ was increased as a result of DADS treatment. The stimulating effect of DADS on the expression of p53 may result from inhibition of cyclin-dependent kinases. ${ }^{[33]}$ It was reported that p53 stimulation produced a dual effect on EAC-cells. It may upregulate the pro-apoptotic protein Bax on one hand and/or mediate growth arrest involving p21 as a major effector on the other. ${ }^{[28,34]}$ Similar to the effect on p53, the DNA fragmentation marker, $\mathrm{TdT}^{[28]}$ also increased as a result of treatment with the tested compound. From these findings, it can be suggested that the induced inhibition of EAC-cell growth and proliferation by DADS are due to induction of apoptosis and cell cycle arrest. These results and suggestion are in accordance with other several publications. ${ }^{[35-37]}$

It was reported that in EAC-bearing mice, extensive formation of new capillary blood vessels (neovascularization or angiogenesis) provides more nutrients and oxygen supply to the highly divided EAC-cells leading to the induction of growth and proliferation. ${ }^{[38-40 \mid}$ Thus, it should not be excluded that DADS may have anti-angiogenic effects which in turn may have a crucial role in anti-proliferative effects. ${ }^{[15]}$

As suggested by Freitas et al. ${ }^{[14]}$ and Senger et al. ${ }^{[41]}$ the production of ascitic extracellular fluid in Ehrlich carcinoma is said to occur due to increased capillary permeability present in the peritoneal cavity. This vascular change occurs due to increased receptor expression for autocrine motility factor (AMF). ${ }^{[14]} \mathrm{AMF}$ link to its receptor induces angiogenesis and changes in endothelial cell morphology causing a subsequent increase in vascular permeability with increased amount of ascitic fluid ${ }^{[42]}$ in addition to the increasing number of proliferated cells. In the present study, the volume of EAC-aliquot relative to total cell count was increased as a result of DADS treatment. In our opinion, this means that the extra-cellular fluid volume was increased at the expense of EAC-cells which exhibited a greater rate of apoptosis and death after treatment with DADS. This assumption was supported by the present histological results which depicted increased extracellular exudates in EAC-bearing mice treated with DADS.

The present in vitro study indicated that DADS succeeded to produce amazing potential anti-tumor cytotoxicity and antiproliferative effects against EAC-cells. These results are in accordance with those obtained by many previous authors who found that DADS cause marked inhibition of HepG2 cell proliferation ${ }^{[6,43,44]}$ and HCT116 cell growth..$^{[2,10]}$ The present results are also in accordance with in vivo studies of Ahmed et al. ${ }^{[45]}$ and Abdel-Aleem et al. ${ }^{[46]}$ who found that DADS had anti-tumor effects in liver and kidney of carbon tetrachloride-intoxicated rats. Different hypotheses have evolved to explain the mechanisms by which DADS produced its anti-carcinogenic effects. García et al..$^{[4]}$ reported that DADS exerted its anti-carcinogenic effect by inhibition of cytochromes CYP2E, CYP2A6 and CYP1A1 and activation of UDP-glucuronyl-transferase. Knowles and Milner, ${ }^{[35]}$ Robert et al. ${ }^{[36]}$ and Oommen et al..$^{[37]}$ stated that the anti-tumor effect of garlic may be due to the induction of apoptosis of tumor cells. Furthermore, Iciek et al. ${ }^{[43]}$ attributed the anti-cancer effects of DADS to both suppression of cell division (stimulation of cell cycle arrest) and induction of apoptosis in tumor cells. This latter postulation is concomitant with the present study, which revealed a decreased expression of anti-apoptotic protein Bcl-2 in cytoplasm and increased levels of pro-apoptotic and cell cycle arrest protein in cytoplasm and nuclei as well as increased concentration of DNA fragmentation marker $\mathrm{TdT}$ in nuclei of tumors cells after treatment with DADS as compared with vehicle. This attribution was supported by imaging and semi-quantitative analysis which revealed that the area in pixels, the percent area and the intensity of yellowish brown color of immunoreactive pro-apoptotic protein, Bcl-2, decreased while those of the yellowish brown colored immunoreactive apoptotic markers, p53 and TdT, increased.

In conclusion, DADS has effective anti-tumor potentials against EAC-cells in both in vivo and in vitro studies. These anti-tumor effects may be mediated via modulation of tumor cell cycle as well as the balance between pro-apoptotic and anti-apoptotic factors.

\section{REFERENCES}

1. Bilecová-Rabajdová $\mathrm{M}$, Birková $\mathrm{A}$, Urban $\mathrm{P}$, Gregová K, Durovcová E, Mareková M. Naturally occurring substances and their role in chemo-protective effects. Cent Eur J Public Health 2013;21:213-9.

2. Jo HJ, Song JD, Kim KM, Cho YH, Kim KH, Park YC. Diallyl disulfide induces reversible $\mathrm{G} 2 / \mathrm{M}$ phase arrest on a $\mathrm{p} 53$-independent mechanism in human colon cancer HCT-116 cells. Oncol Rep 2008;19:275-80.

3. Thakur VS, Deb G, Babcook MA, Gupta S. Plant phytochemicals as epigenetic modulators: role in cancer chemoprevention. AAPS J 2014;16:151-63.

4. Le Bon AM, Siess MH. Organosulfur compounds from Allium and the chemoprevention of cancer. Drug Metabol Drug Interact 2000;17:51-79.

5. Thomson M, Ali M. Garlic [Allium sativum]: a review of its potential use as an anti-cancer agent. Curr Cancer Drug Targets 2003;3:67-81.

6. Wen J, Zhang Y, Chen X, Shen L, Li GC, Xu M. Enhancement of diallyl disulfide-induced apoptosis by inhibitors of MAPKs in human HepG2 hepatoma cells. Biochem Pharmacol 2004;68:323-31.

7. Herman-Antosiewicz A, Singh SV. Signal transduction pathways leading to cell cycle arrest and apoptosis induction in cancer cells by Allium vegetable-derived organosulfur compounds: a review. Mutat Res 2004;555:121-31.

8. Belloir C, Singh V, Daurat C, Siess MH, Le Bon AM. Protective effects of garlic sulfur compounds against DNA damage induced by direct- and 
indirect-acting genotoxic agents in HepG2 cells. Food Chem Toxicol 2006;44:827-34.

9. Fleischauer AT, Arab L. Garlic and cancer: a critical review of the epidemiologic literature. J Nutr 2001;131:S1032-40.

10. Bottone FG Jr, Baek SJ, Nixon JB, Eling TE. Diallyl disulfide (DADS) induces the antitumorigenic NSAID-activated gene (NAG-1) by a p53-dependent mechanism in human colorectal HCT 116 cells. J Nutr 2002;132:773-8

11. Xiang SL, Xiao XL, Ling H, Liao QJ, Zhou XT, Dong L, Su Q. Antitumor effect of diallyl disulfide on human gastric cancer MGC803 cells xenograft in nude mice. Ai Zheng 2005;24:940-4.

12. Yuan XK, Chen XQ, Jiang XY, Nie YL. Synthesis, characterization and bioactivity of diallyl disulphide. J Cent S Univ Technol 2006;13:515-8.

13. Freshney RI. Culture of Animal Cells: a Manual of Basic Technique. 3rd ed. New York: Wiley; 1994.

14. Freitas ES, Leite ED, Silva AE, Ocarino NM, Ferreira E, Gomes MG, Cassali GD, Serakides R. Effect of thyroxine and propylthiouracil in Ehrlish asitic tumor cells. Int J Morphol 2006;24:665-71.

15. Chandru H, Sharada AC, Bettadaiah BK, Kumar CS, Rangappa KS, Sunila, Jayashree K. In vivo growth inhibitory and anti-angiogenic effects of synthetic novel dienone cyclopropoxy curcumin analogs on mouse Ehrlich ascites tumor. Bioorg Med Chem 2007;15:7696-703.

16. Warren L. The thiobarbituric acid assay of sialic acids. J Biol Chem 1959;234:1971-5.

17. Negoescu A, Lorimier P, Labat-Moleur F, Drouet C, Robert C, Guillermet C, Brambilla C, Brambilla E. In situ apoptotic cell labeling by the TUNEL method: improvement and evaluation on cell preparations. J Histochem Cytochem 1996;44:959-68.

18. Gao H, Zhou YW. Inhibitory effect of picroside II on hepatocyte apoptosis. Acta Pharmacol Sin 2005;26:729-36.

19. Ahmed OM, Ahmed RR. Anti-proliferative and apoptotic efficacies of ulvan polysaccharides against different types of carcinoma cells in vitro and in vivo. J Cancer Sci Ther 2014;6:202-8.

20. Rao M, Blane K, Zonneberg M. PC-STAT programs, version 1A (C), one and two way analysis of variance. Athens, GA: The University of Georgia; 1985.

21. Arican G, Arican E. Evaluation of the apoptotic and anti-proliferative activities of paclitaxel in Ehrlish ascites tumor cells. Biotechnol Biotechnol Equip 2006;20:69-75.

22. Ozen N, Uslu E, Ozen M, Aydin S, Altug T, Belce A, Kokoglu E. Curcumin's effects on sialic acid level and sialidase activity in Ehrlich ascites tumor bearing mice. Tohoku J Exp Med 2002;197:221-7.

23. Kuttan G, Kuttan R. Effect of diallyl sulphide, diallyl disulphide, and allyl methyl sulphide on the inhibition of lung metastasis of B16F-10 melanoma cells in mice. J Clin Biochem Nutr 1999;27:131-9.

24. Vijay V, Vickram, Raiker VG, Kashinath RT. Effect of diallyl disulphide on renal glycated proteins and plasma sialic acid levels in alloxan diabetic rats. Glob J Med Res 2011;11:31-5.

25. Gunadharini DN, Arunkumar A, Krishnamoorthy G, Muthuvel R, Vijayababu MR, Kanagaraj P, Srinivasan N, Aruldhas MM, Arunakaran J. Antiproliferative effect of diallyl disulfide (DADS) on prostate cancer cell line LNCaP. Cell Biochem Funct 2006;24:407-12.

26. Sriram N, Kalayarasan S, Ashokkumar P, Sureshkumar A, Sudhandiran G. Diallyl sulfide induces apoptosis in Colo 320 DM human colon cancer cells: involvement of caspase-3, NF-kappaB, and ERK-2. Mol Cell Biochem 2008;311:157-65.

27. Mondal S, Bandyopadhyay S, Ghosh MK, Mukhopadhyay S, Roy S, Mandal C. Natural products: promising resources for cancer drug discovery. Anticancer Agents Med Chem 2012;12:49-75.

28. Bhattacharyya A, Choudhuri T, Pal S, Chattopadhyay S, Datta GK, Sa G, Das T. Apoptogenic effects of black tea on Ehrlich's ascites carcinoma cell. Carcinogenesis 2003;24:75-80.

29. Hussein AM, Ahmed OM. Regioselective one-pot synthesis and anti-proliferative and apoptotic effects of some novel tetrazolo[1,5-a] pyrimidine derivatives. Bioorg Med Chem 2010;18:2639-44.

30. Meng LH, Zhang H, Hayward L, Takemura H, Shao RG, Pommier Y. Tetrandrine induces early G1 arrest in human colon carcinoma cells by down-regulating the activity and inducing the degradation of G1-S-specific cyclin-dependent kinases and by inducing p53 and p21Cip1. Cancer Res 2004;64:9086-92.

31. Chen Y, Miao ZH, Zhao WM, Ding J. The p53 pathway is synergized by 38 MAPK signaling to mediate 11,11 '-dideoxyverticillin-induced G2/M arrest. FEBS Lett 2005;579:3683-90.

32. Ianzini F, Bertoldo A, Kosmacek EA, Phillips SL, Mackey MA. Lack of p53 function promotes radiation-induced mitotic catastrophe in mouse embryonic fibroblast cells. Cancer Cell Int 2006;6:11.

33. Ahmed OM, Mohamed MA, Ahmed RR, Ahmed SA. Synthesis and anti-tumor activities of some new pyridines and pyrazolo[1,5-a] pyrimidines. Eur J Med Chem 2009;44:3519-23.

34. Deng $\mathrm{Y}, \mathrm{Wu} \mathrm{X}$. Peg3/Pw1 promotes $\mathrm{p} 53$-mediated apoptosis by inducing Bax translocation from cytosol to mitochondria. Proc Natl Acad Sci US A 2000;97:12050-5.

35. Knowles LM, Milner JA. Possible mechanism by which allyl sulfides suppress neoplastic cell proliferation. J Nutr 2001;131:S1061-6.

36. Robert V, Mouillé B, Mayeur C, Michaud M, Blachier F. Effects of the garlic compound diallyl disulfide on the metabolism, adherence and cell cycle of HT-29 colon carcinoma cells: evidence of sensitive and resistant sub-populations. Carcinogenesis 2001;22:1155-61.

37. Oommen S, Anto RJ, Srinivas G, Karunagaran D. Allicin (from garlic) induces caspase-mediated apoptosis in cancer cells. Eur J Pharmacol 2004;485:97-103.

38. Folkman J. Tumor angiogenesis: therapeutic implications. NEngl JMed 1971;285:1182-6.

39. Risau W. Mechanisms of angiogenesis. Nature 1997;386:671-4.

40. Bergers G, Benjamin LE. Tumorigenesis and the angiogenic switch. Nat Rev Cancer 2003;3:401-10.

41. Senger DR, Galli SJ, Dvorak AM, Perruzzi CA, Harvey VS, Dvorak HF. Tumor cells secrete a vascular permeability factor that promotes accumulation of ascites fluid. Science 1983;219:983-5.

42. Funasaka T, Haga A, Raz A, Nagase H. Tumor autocrine motility factor induces hyperpermeability of endothelial and mesothelial cells leading to accumulation of ascites fluid. Biochem Biophys Res Commun 2002;293:192-200.

43. Iciek MB, Rokita HB, Wlodek LB. Effects of diallyl disulfide and other donors of sulfane sulfur on the proliferation of human hepatoma cell line (HepG2). Neoplasma 2001;48:307-12.

44. De Martino A, Filomeni G, Aquilano K, Ciriolo MR, Rotilio G. Effects of water garlic extracts on cell cycle and viability of HepG2 hepatoma cells. J Nutr Biochem 2006;17:742-9.

45. Ahmed OM, Abdel-Aleem SR, Mossa NM. Chemopreventive effect of diallyl disulphide on $\mathrm{CCl}_{4}$-induced liver injury in albino rats. $J$ Egypt Ger Soc Zool 2008;56A: 25-62.

46. Abdel-Aleem SR, Ahmed OM, Mossa NM. Chemopreventive effects of diallyl disulphide on $\mathrm{CCl}_{4}$-induced kidney injury and haematological disturbances in albino rats. J Egypt Ger Soc Zool 2007;55C: 389-419.

47. García A, Haza AI, Arranz N, Delgado ME, Rafter J, Morales P. Organosulfur compounds alone or in combination with vitamin $\mathrm{C}$ protect towards N-nitrosopiperidine- and N-nitrosodibutylamine-induced oxidative DNA damage in HepG2 cells. Chem Biol Interact 2008;173:9-18.

How to cite this article: Ahmed OM, Ahmed RR. Anti-proliferative and apoptotic efficacy of diallyl disulfide on Ehrlich ascites carcinoma. Hepatoma Res 2015;1:67-74.

Source of Support: Nil. Conflict of Interest: None declared. 